\title{
Idades / Ages
}

https://doi.org/10.21814/uminho.ed.36.35

\section{Iván Pascual}

Universidad de Huelva, España 



\section{Idades}

Sendo um termo polissémico, idades possui vários significados: 1. como uma forma plural do substantivo "idade", que se refere ao tempo em que uma pessoa viveu ou existiu, mas também 2. refere-se aos períodos ou fases da própria vida humana ou do seu ciclo de vida, ou 3. (menos frequentemente) entende-se como ciclos e períodos históricos de vida de sociedades e instituições. Geralmente, aparece relacionado, sob diferentes termos associados, ao desenvolvimento da pessoa e, em particular, da população infantil e adolescente. Para além disso, mais do que uma categoria geral absoluta, é a denominação de um atributo que é representado por indivíduos ou grupos de indivíduos, a partir do qual são extraídas certas expectativas sociais referentes às suas capacidades e à sua posição social.

Este e outros termos referentes à maturidade e à sua implementação na vida pessoal são problemáticos do ponto de vista sociológico e têm sido objeto de estudo aprofundado nas últimas décadas. Embora o desenvolvimento humano e o curso do tempo evolutivo possam parecer categorias invariáveis e associadas à biologia, alertou-se logo, a partir da Sociologia da Infância, sobre o erro de se pressupor que a idade é uma simples condição biofísica do desenvolvimento humano e que, por isso, este era um conceito não suscetível de crítica ou revisão a partir de um paradigma sócio antropológico. Por um lado, porque muitas das distinções sociais - cuja fundamentação se baseia nas idades são recentes e estão longe de estar ancoradas no biológico -, são completamente arbitrárias. Disso é exemplo a organização por faixas etárias, presente nos sistemas educativos ou dos limites legais que marcam, em muitas sociedades, o acesso ao mundo adulto. Por outro lado, a mesma noção de desenvolvimento evolutivo, que descreve a passagem pelas diferentes idades na vida das crianças, tem sido questionada na medida em que se torna num discurso que reflete grande parte das primeiras noções sobre a infância que existe numa sociedade centrada no adulto.

Esta situação acontece na medida em que, embora procure refletir um processo de corte biológico e psicológico, acabou por ser uma importante influência discursiva no processo de construção social da própria categoria de Infância, como é bem descrito em Woodhead (2009). Aqui, o autor 
descreveu de que forma a categoria idade se tornou parte, com o surgimento de estudos científicos da vida infantil a partir do final do século XIX, de um conjunto de forças e discursos que moldavam o conceito moderno de infância (em conjunto com o género, classe social ou a religiosa, para citar algumas).

A literatura fundamental dos chamados novos estudos sociais da infância logo ecoou esta particularidade. Um dos seus representantes mais importantes, Jens Qvortrup (1994), aponta para a observação das diferentes idades da criança, em oposição ao estatuto dos restantes indivíduos da sociedade, como um dos principais argumentos de apoio ao suposto direito "natural" do adulto de governar a vida dos primeiros. Consequentemente, as várias idades da população infantil e adulta também serão o núcleo argumentativo e legítimo das várias formas de discriminação com base na idade, denominadas de "etarismo [idadismo]" ou, de forma mais habitual e num sentido mais amplo do que o critério etário, de "adultismo". Questionar os discursos que surgem da observação adulta das idades da infância - da própria idade como critério que caracteriza as capacidades individuais das crianças - sem negar o óbvio, que é a existência comprovada de um processo individual de amadurecimento e desenvolvimento. Essa tem sido uma das principais tarefas da sociologia da infância e de outras disciplinas relacionadas. $\mathrm{O}$ seu objetivo é exigir uma reconstrução da posição social das crianças na sociedade que dê destaque ao seu papel ativo (a partir de qualquer idade) como co-construtores da mesma. Um exemplo prático das consequências deste desafio ontológico leva-nos às práticas metodológicas, onde a insistência dos investigadores em desafiar as fronteiras do amadurecimento que pensávamos conhecer - abrindo a investigação para formulações menos focadas na normatividade adulta e mais na ação e contexto infantil - conduziu a que a disciplina reduzisse consideravelmente as idades em que se estimava que a população infantil se poderia converter no informador principal nos dispositivos de investigação (Platt, 2016).

(Tradução de Luana Dias Gonzaga)

\section{Ages}

"Ages" is a polysemic term, and thus has several meanings: (1) as the plural form of the noun "age," referring to the duration of a person's life; (2) signifying the periods or phases of one human being's life or of her/his cycle of development; (3) (less frequently) referring to the historical cycles or 
periods of duration of societies and institutions. Normally, it is used in relation to other terms linked to the person's development, and in particular to that of the child and adolescent population; more than an absolute general category, it is the noun standing for an attribute of individuals or groups of individuals, and from which specific social expectations are extrapolated, in terms of their abilities and social positions.

This and other terms referring to the time sequence of growth and maturation in the lives of individuals are problematic from the sociological point of view, and thus have been objects of critical study in recent decades. Although human growth and the progress of developmental time may seem to be invariable categories linked to biology, sociology of childhood warned early on that it was an error to assume age to be a simple biophysical condition of human development and that therefore the concept was not open to criticism or reassessment within the socio-anthropological paradigm: firstly because many social distinctions that draw their rationale from the different ages are recent and, far from being anchored in biology, completely arbitrary (for example the organisation of age groups in education systems and the legal frontiers that in many societies mark access to the adult world); secondly because the very notion of staged development, which describes how children pass through different ages in their lives, has been called into question for its tendency to turn into discourse largely reflecting the preconceptions of an adult-centred society towards childhood.

Thus, although it claims to reflect a biological and psychological process, this notion has in fact become a strong discursive influence on the social construction of the category of Childhood itself, as Woodhead (2009) shows clearly, observing that since the rise of scientific studies of children's lives at the end of the 19th century, the category of age has become part of the set of forces and discourses constructing the modern concept of childhood (together with gender, social class and religion, to cite some others).

The founding texts of what are now called the new social studies of childhood soon began to discuss this particularity. One of the main scholars in the field, Jens Qvortrup (1994), indicates that the observation of the different ages of childhood, counterposed to the status of the rest of the individuals in society, is one of the main foundations of the supposedly "natural" right of adults to direct the lives of children. Consequently, the different ages of the child and adult population are also core arguments legitimizing the various forms of age-based discrimination termed "ageism" or more usually, and in a wider sense than the age-related term, "adultism." Questioning 
the discourses arising from adult observation of the ages of Childhood e.g., from one's own age as a criterion used to define the individual abilities of children - without denying the obvious (the proven existence of an individualised process of maturation and development) has been one of the main tasks of the sociology of childhood and other kindred disciplines. And the outcome has been a call for the reconstruction of the social position of children, emphasizing their active role (at whatever age) as co-constructors of society. A practical example of the results of this ontological challenge is in research methodology, where researchers' determination to challenge the existence of the maturational boundaries believed to exist has opened up their work to approaches that are centered less on adult norms and more on children's agency and context. This has led scholars to lower considerably the ages at which it was thought children could become key informants in research studies (Platt, 2016).

\section{Referências / References}

Platt, L. (2016). Conducting qualitative and quantitative research with children of different ages. London: Global Kids Online. Disponível em: www.globalkidsonline.net/young-children

Qvortrup, J. (1994). Childhood Matters: An Introduction. In J. Qvortrup, M. Bardy, G. Sgritta, \& H. Wintersberger (Eds.), Childhood Matters: Social Theory, Practice and Politics (pp. 1-24). Aldershot: Avebury Press and Vienna, European Centre.

Woodhead, M. (2009). Child Development and the Development of Childhood. In Qvortrup, J., Corsaro, W. \& Honig M. S. (Eds.). The Palgrave Handbook of Childhood Studies (pp. 46-61). London: Palgrave Macmillan. 